\title{
PERILAKU BALOK BAJA I BUILT-UP
}

\author{
Titin Sundari \\ Teknik Sipil Fakultas Teknik Universitas Hasyim Asy’ari, \\ e-mail: tari1273@yahoo.co.id
}

\begin{abstract}
Abstrak
Balok adalah komponen struktur lentur yang memikul beban gravitasi, beban gravitasi ini berupa beban mati dan beban hidup yang bekerja tegak lurus dengan sumbu longitudinal balok. Salah satu bentuk balok yang efisien adalah balok profil I yang dibentuk dengan pengelasan atau yang dikenal dengan sebutan balok baja I built-up. Dalam penelitian eksperimental ini, balok baja dibuat dengan memotong lembaran pelat baja menjadi elemenelemen pelat sayap dan pelat badan dengan menggunakan pengelasan sehingga membentuk suatu balok baja profil I (balok baja I built-up). Sedangkan konstruksi balok yang digunakan adalah konstruksi balok sederhana (simple beam) dengan beban terpusat di tengah bentang. Penelitian ini bertujuan menganalisis kapasitas lentur dan mengetahui perilaku tekuk balok baja I built-up. Hasil dari ekeperimen ini dibandingkan dengan perhitungan sesuai SNI 03-1729-2002 dan validasi dengan menggunakan software ANSYS.

Dari penelitian ini didapatkan kapasitas lentur beradasarkan eksperimen lebih tinggi dibanding dengan SNI 031729-2002 dan ANSYS. Sedangkan keruntuhan yang terjadi adalah keruntuhan tekuk torsi lateral.
\end{abstract}

Kata kunci : built-up, momen kapasitas, tekuk torsi lateral

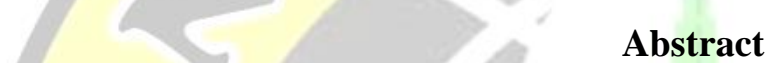

Beam is a structural member that carries a dead load or live load that works perpendicular to its longitudinal axis is beam. One form of an efficient beam is a beam profile I which is formed by welding or known as I built-up beam.

In this experimental study, the steel beam is made by cutting the sheet of steel plate into wing plate elements and body plate by using welding to form a steel profile I (steel beam I built-up). The construction of beam is used a simple beam with concentrated load in the middle of the span. This study aims to obtain bending capacity and know the buckling behavior of I built-up steel beam. The result of this experiment is compared with the calculation according to SNI 03-1729-2002 and validation using ANSYS software.

From this research, the bending capacity based on experiments is higher than that of SNI 03-1729-2002 and ANSYS. While the collapse that occurs is the collapse of lateral torsional buckling.

Keywords : built-up, bending capacity, lateral torsional buckling

\section{PENDAHULUAN}

Balok merupakan komponen struktur lentur yang menahan beban gravitasi yang bekerja tegak lurus dengan sumbu longitudinalnya. Beban gravitasi ini bisa berbentuk beban mati maupun beban hidup. Bentuk balok yang efisien adalah yang menggunakan bahan sejauh-jauhnya dari garis netral karena semakin jauh suatu bahan dari garis netral maka akan semakin besar modulus penampangnya sehingga semakin besar pula momen lentur yang dapat ditahan. Tetapi tentunya ada batas praktek dalam memperbesar tinggi balok, karena balok akan menjadi tidak stabil dalam arah lateral apabila rasio tinggi balok $(h)$ terhadap lebar $(b)$ terlalu besar. Balok baja profil I hot rolled, atau balok baja profil I built-up adalah salah satu contoh bentuk balok yang efisien. Balok baja I built-up ini dibuat karena tidak semua profil I hot rolled dengan ukuran yang kita butuhkan tersedia di pasaran

Balok baja I built-up ini dibuat dengan memotong lembaran pelat baja menjadi elemen-elemen pelat sayap dan pelat badan dengan menggunakan pengelasan sehingga membentuk suatu balok baja profil $I$. Penelitian ini bertujuan untuk menganalisis kapasitas lentur dan mengetahui perilaku tekuk balok baja I built-up

\section{KAJIAN PUSTAKA}

Suatu balok jika diberikan beban, semula balok akan berperilaku elastis yaitu jika beban dihilangkan maka kondisi geometri akan kembali seperti semula, tetapi jika beban ditingkatkan terus sampai leleh dengan tegangan lebih besar dari tegangan lelehnya $\left(f>f_{y}\right)$ maka akan berperilaku plastis yaitu jika beban dihilangkan akan ada deformasi sehingga tidak kembali ke posisi semula.

Sebagaimana terlihat pada Gambar 1, jika beban ditingkatkan terus serat terluar akan mencapai leleh $\left(f_{y}\right)$ yang berarti perilaku elastis berakhir dan perilaku plastis dimulai, jika kemudian beban ditingkatkan lagi maka penyebaran tegangan leleh akan ke serat lain penampang sampai dengan seluruh penampang leleh dan terbentuklah penampang plastis. Pada kondisi seperti ini balok sudah tidak mempunyai kekakuan lentur, jadi jika beban ditingkatkan lagi sedikit saja akan terjadi rotasi yang besar. Perilaku ini yang dikenal sebagai terbentuknya sendi plastis. 


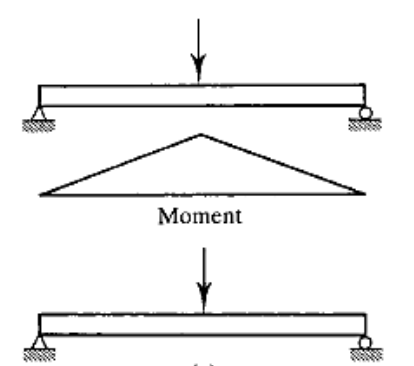

(a)

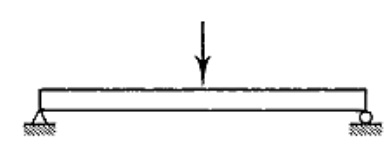

(b)

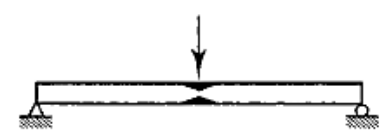

(e)

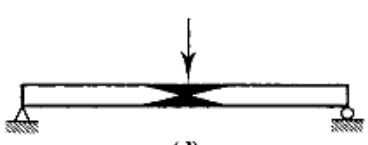

(d)
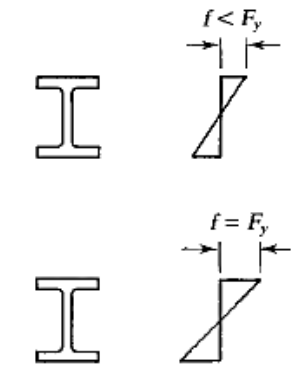

Gambar 1. Pembebanan elastis-plastis akibat momen Sumber: Segui, W. T (2007: 192)

Ada empat (4) perilaku balok yang memikul momen lentur. Seperti terlihat pada Gambar 2 yang menunjukkan perilaku dari sebuah balok yang dibebani momen konstan $M$ dengan bentang tak terkekang $L$, yaitu:

1. Kekuatan momen plastis $M_{p}$ tercapai dengan kapasitas rotasi R. $\Delta_{H}$ yang cukup besar. Penampang seperti ini diijinkan dalam analisis dengan metoda plastis. $\left(L \leq L_{p d}\right)$.

2. Kekuatan momen plastis $M_{p}$ tercapai dengan kapasitas rotasi yang kecil. Hal ini karena kekakuan sayap atau kekakuan badan kurang untuk menahan tekuk lokal atau lateral support tidak memadai untuk menahan tekuk lateral dalam keadaan kondisi inelastis. Penampang ini tidak diijinkan analisis dengan metoda plastis. $\left(L_{p d}<L<L_{p}\right)$.

3. Kekuatan momen hanya mampu mencapai $M_{r}$ dengan kapasitas rotasi yang sangat terbatas. Adanya tekuk lokal pada sayap atau badan atau tekuk torsi lateral mencegah tercapainya kapasitas momen plastis $M_{p} .\left(L_{p}<L<L_{r}\right)$.

4. Perilaku elastis $\left(L>L_{r}\right)$, dengan tahanan momen $M_{c r}$ ditentukan oleh tekuk elastis baik akibat local buckling pada sayap atau badan, atau tekuk tosi lateral (lateral torsional buckling).

Sebagaimana ditunjukkan pada gambar 2, untuk menghitung tekuk torsi lateral momen dianggap konstan sepanjang $L$, jika diagram momen tidak konstan atau membentuk momen gradien, sehingga luasan momennya lebih kecil dibanding sebelumnya maka tentunya momen kritis dapat ditingkatkan dengan memodifikasi rumus $\mathrm{Mcr}$ yang ada dengan memberikan faktor $C b>1$.

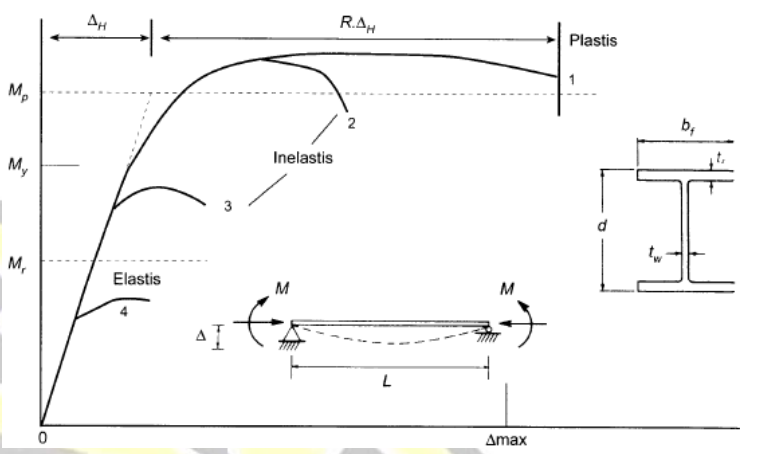

Gambar 2. Balok dengan beban momen konstan tanpa kekangan lateral

Sumber: Setiawan A. (2008:180)

Untuk balok dengan perletakan/tumpuan sederhana diberi beban terpusat $P$ di tengah bentangnya, maka diagram momennya adalah bilinier. Tekuk torsi lateral pada balok profil $I$ dengan perletakan sederhana dan beban terpusat ditengah bentang digambarkan pada Gambar 3 .

Untuk balok dengan momen ujung yang tidak sama, Salvadory telah mengusulkan bahwa efek dari momen gradien untuk momen kritis $M_{c r}$ dapat dengan mudah dihitung dengan menggunakan equivalen moment factor $C_{b}$. Momen kritis untuk balok ini adalah:

$$
M_{c r}=C_{b} \cdot M_{o c r}
$$

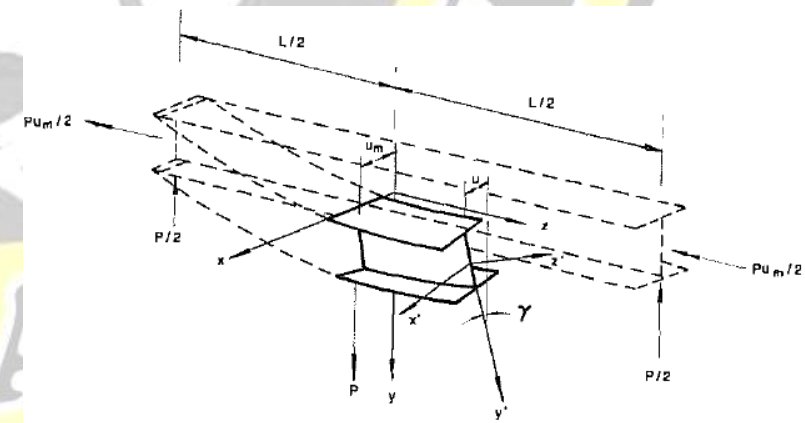

Gambar 3 Tekuk lateral simply I beam dengan beban di tengah bentang

Sumber: Chen, W. F and Lui, E. M (1987: 329)

Pembebanan dengan diagram momen yang tidak konstan, diberikan pada Tabel 1, sebuah formula empiris diberikan oleh Kirby dan Nethercot untuk nilai $\mathrm{Cb}$ dapat dipakai:

$C_{b}=\frac{12}{2\left(\frac{M 1}{M \operatorname{mac}}\right)+4\left(\frac{M 2}{M \max }\right)+3\left(\frac{M 3}{M \max }\right)+2}$

dengan: 


$$
\begin{array}{ll}
M_{1} & =\text { Momen di } 1 / 4 \text { bentang } \\
M_{2} & =\text { Momen di tengah bentang } \\
M_{3} & =\text { Momen di } 3 / 4 \text { bentang } \\
M_{\max } & =\text { Momen maksimum pada } \\
& \text { balok sepeti ditunjukkan Tabel1. }
\end{array}
$$

Tabel1 Nilai $\mathrm{Cb}$ untuk Berbagai Kasus Pembebanan yang Berbeda (Semua Beban Diaplikasikan pada Pusat Geser Penampang Melintang)

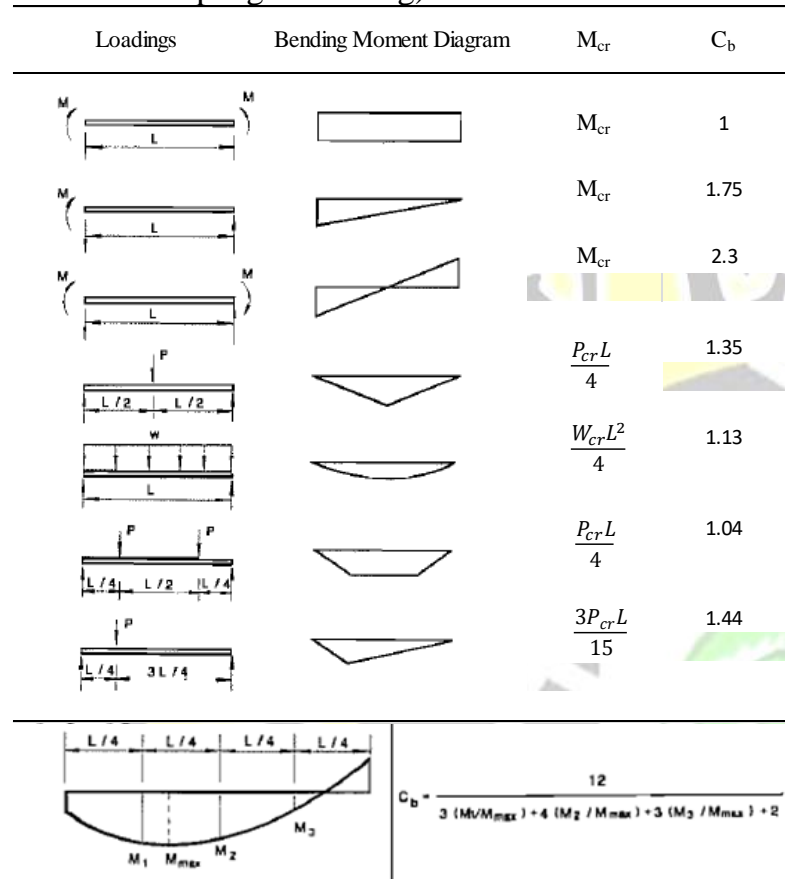

Sumber: Chen, W. F and Lui, E. M (1987: 334)

\section{METODE PENELITIAN}

Penelitian ini termasuk dalam penelitian eksperimental yang dilakukan di laboratorium, perhitungan analisis sesuai SNI 03-1729-2002, dan validasi numerik dengan menggunakan software ANSYS sebagai pembanding. Pembuatan benda uji dilakukan di VEDC Malang dan pengujian dilakukan di Laboratorium Struktur dan Bahan Konstruksi Jurusan Teknik Sipil Fakultas Teknik Universitas Negeri Malang.

\section{Bahan dan Alat}

Bahan yang digunakan adalah lembaran pelat baja $120 \mathrm{~mm}$ x $240 \mathrm{~mm}$ yang ada di pasar kota Malang dengan tebal $2 \mathrm{~mm}$ dan $3 \mathrm{~mm}$ dengan mutu baja fy 240 $\mathrm{MPa}$. Alat dan bahan yang digunakan dalam penelitian ini adalah sebagai berikut:
a. UTM (Universal Testing Machine)
b. Loading Frame, untuk setting up pengujian
c. Hydraulic Jack, untuk memberikan beban pada benda uji
d. Load cell, untuk membaca besar beban yang diberikan pada benda uji melalui hydraulic jack.
e. Transducer, untuk membaca besarnya perpindahan dari benda uji.

f. Dial gage, untuk membaca besarnya perpindahan dari benda uji.

g. Strain Gauge, untuk mengetahui besarnya regangan yang terjadi pada benda uji.

h. Strainmeter, untuk membaca besarnya regangan pada benda uji.

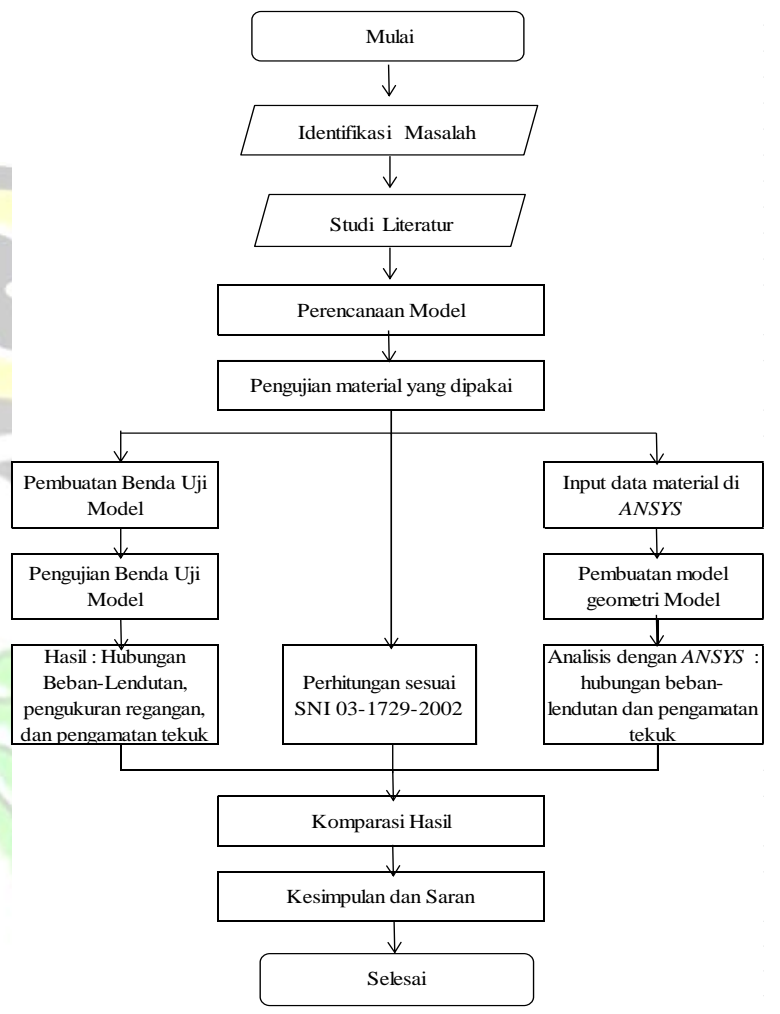

Gambar 4. Diagram Alir Penelitian

\section{Rancangan Penelitian}

Jumlah benda uji yang digunakan dalam penelitian eksprimen ini adalah dua (2) buah dengan panjang bentang $L=1350 \mathrm{~mm}$, ditambah panjang untuk dudukan $150 \mathrm{~mm}$, dengan tinggi web $h_{w}=90$ $\mathrm{mm}$, lebar flens $b_{f}=50 \mathrm{~mm}$, tebal flens $t_{f}=3 \mathrm{~mm}$, dan tebal badan $t_{w}=2 \mathrm{~mm}$. Untuk lebih jelasnya model benda uji beserta ukuran penampang ditunjukkan pada gambar 5 . 


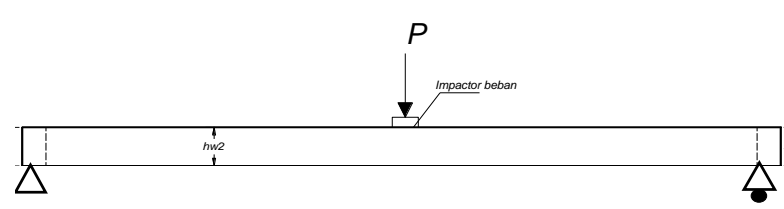

(c)

Gambar 5.

a. sketsa model benda uji/specimen

b. ukuran penampang benda uji

c. ilustrasi setting-up pengujian

\section{HASIL DAN PEMBAHASAN \\ Pengujian Eksperimental}

Setting up pengujian dilakukan seperti pada Gambar 6a. Penempatan dial gage pada sisi belakang dan bawah specimen, tranducer di sisi depan specimen ditunjukkan Gambar 5b. Pemasangan strain gage dipasang di sayap atas bagian bawah dan sayap bawah bagian bawah specimen.

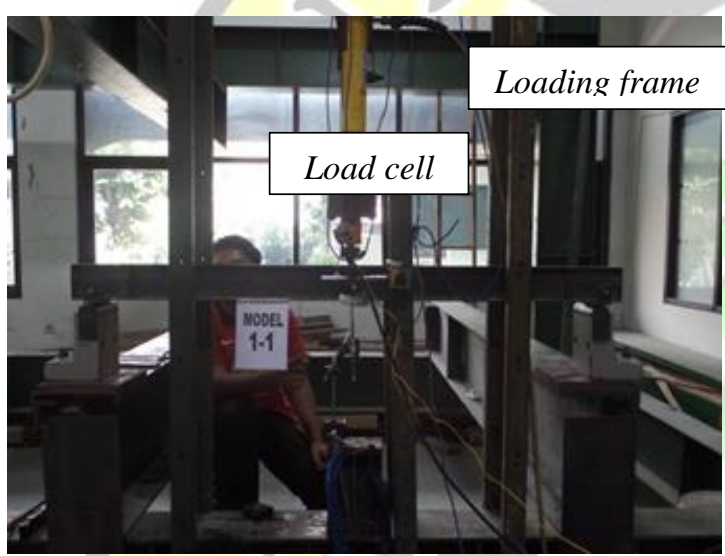

Gambar 6a. Setting up pengujian laboratorium

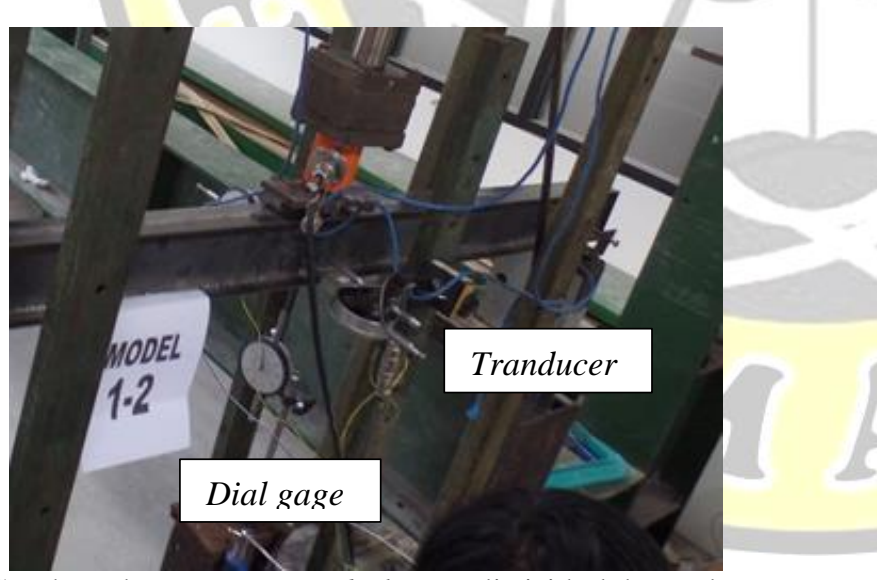

Gambar 6b. Penempatan dial gage di sisi belakang dan bawah, dan tranducer di sisi depan specimen

Dalam eksperimen ini kekakuaan sayap $\left(\lambda=b / 2 . t_{f}\right)$ maupun kekakuan badan $\left(\lambda=h / t_{w}\right)$ dibuat kompak $<\left(\lambda_{p}\right)$ sesuai SNI 03-1729-2002 untuk mencegah terjadinya tekuk lokal pada sayap atau badan. Stiffner dipasang hanya pada tumpuan.

UJi specimen menggunakan loading frame dengan hydraulic jack berkapasitas 20 ton, pemberian beban dilakukan secara bertahap setiap $0,50 \mathrm{kN}$ sampai specimen mengalami keruntuhan. Stiffner dipasang hanya pada tumpuan sehingga $L>L_{p}$ yang disyaratkan dan keruntuhan yang terjadi adalah tekuk torsi lateral. Keruntuhan ini terjadi sebelum kapasitas penampang mencapai $M_{p}$. Adanya tekuk lateral (kesamping) ini mula-mula kecil sekali lama kelamaan bisa dilihat kasat mata mulai tidak stabilnya sayap atas dan sayap bawah yaitu sayap atas akan bergerak ke arah samping dan sayap bawah bergerak ke arah samping lainnya. Nilai lendutan kesamping ini meskipun kecil akan terbaca oleh tranducer/dial gage yang dipasang di sisi depan atau sisi belakang specimen. Tekuk torsi lateral ini seperti tunjukkan dipada Gambar 7.

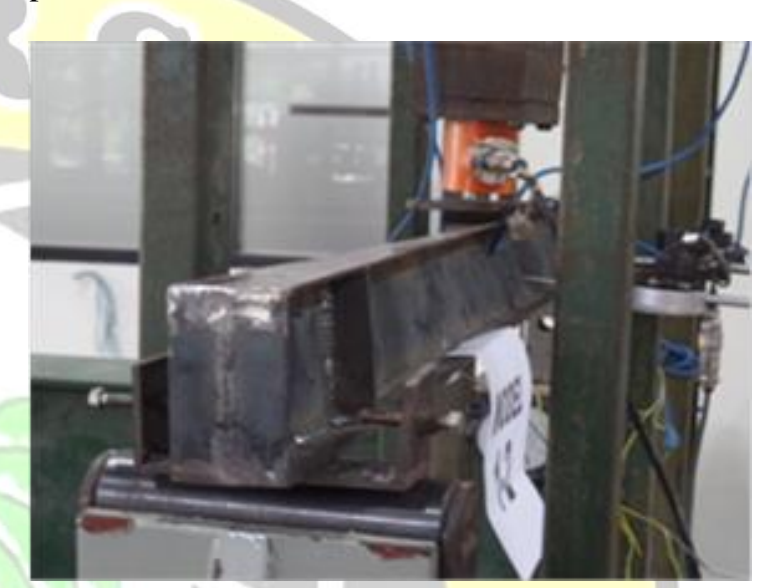

Gambar 7. Keruntuhan tekuk torsi lateral specimen

Dari eksperimen ini didapatkan kurva bebanlendutan seperti pada Gambar 6 dan diagram regangan seperti pada Gambar 7. Pada Gambar 6 terlihat bahwa pada Model 1-1 beban maksimum mencapai $\mathrm{P}=12$ $\mathrm{kN}$, sedangkan pada Model 1-2 beban maksimum hanya mencapai $7.1 \mathrm{kN}$, hal ini karena kesalahan pada pemberian beban yaitu setelah beban mencapai $3.5 \mathrm{kN}$, turun menjadi $1.5 \mathrm{kN}$, kemudian naik lagi menjadi 3,6 $\mathrm{kN}$ dan seterusnya sampai dengan $6.9 \mathrm{kN}$ pemberian beban dihentikan karena dikhawatirkan tranducer sisi depan/belakang terlempar seperti pada pengujian Model 1-1. Dari pengamatan ini momen dihitung :

Pmaks $=12 \mathrm{kN}$

$\mathrm{Mu}=1 / 4 \mathrm{P} \mathrm{L}=1 / 4 * 12 * 1.350=4.05 \mathrm{kNm}$

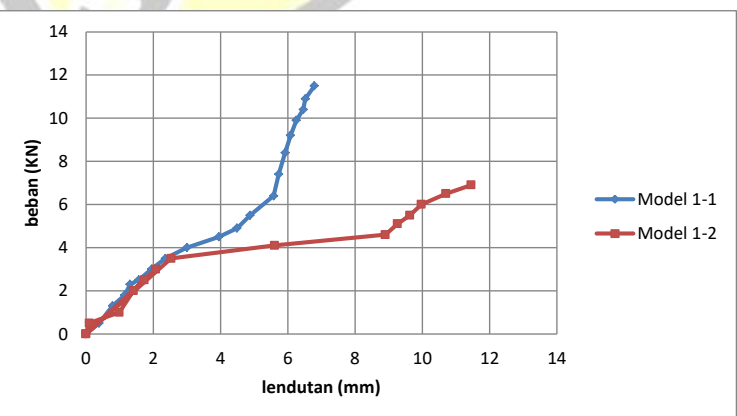

Gambar 8. Kurva beban-lendutan

Gambar 7 menunjukkan diagram regangan model 1-1 bahwa pada beban $P=0.5 \mathrm{kN}$ sampai dengan $4.5 \mathrm{kN}$ 
regangan pada sayap atas dan sayap bawah masih stabil tetapi pada beban $\mathrm{P}=4.9 \mathrm{kN}$ ketidakstabilan sayap atas dan bawah mulai terjadi yang berarti mulai terjadinya tekuk torsi lateral $(L T B)$. Kondisi ini ditandai dengan turunnya garis netral dengan regangan pada sayap atas telah mencapai $0.00187 \geq \varepsilon_{y}=0.00186$ dan regangan pada sayap bawah 0.00136 . Tekuk torsi lateral ini juga ditandai dengan adanya lendutan kesamping. Kemudian beban ditingkatkan terus, keruntuhan total specimen terjadi pada saat beban $P=12 \mathrm{kN}$.

\section{Perhitungan Analisis sesuai SNI 03-1729-2002}

Perhitungan momen kapasitas penampang sesuai dengan syarat-syarat yang ada di SNI 03-1729-2002 adalah sebagai berit:

Data material model

$$
\begin{aligned}
& f y=252.24 \mathrm{Mpa} \\
& f u=345.23 \mathrm{Mpa} \\
& E s=194406 \mathrm{Mpa}
\end{aligned}
$$

Poisson ratio $(v)=0.30$

Modulus geser, $G=E / 2(1+v)=74771.64 \mathrm{Mpa}$

Panjang bentang, $L=1350 \mathrm{~mm}$

Data penampang

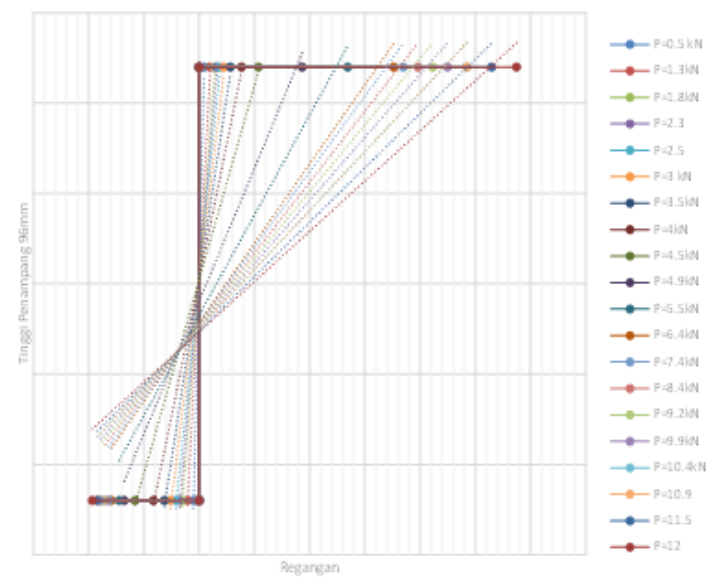

Gambar 7a. Diagram regangan Model 1-1

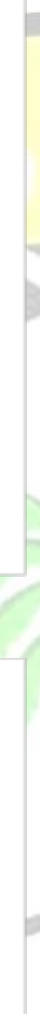

$d$

$\mathrm{b}=$

$\mathrm{tf}=$

hw $=$

$\mathrm{tw}=$

$\mathrm{A}=$

$\mathrm{Ix}=$

Iy $=$

$r y=\sqrt{ }(I y / A)$

$S x=I x /(d / 2)$

$\mathrm{Zx}=$

$J=\Sigma 1 / 3 \cdot b \cdot t^{3}$

$C w=$ If $. h^{2} / 2$

$\mathrm{X} 1=$

$\mathrm{X} 2=$

$96 \mathrm{~mm}$

50

3

90

2

$\mathrm{mm}$

$62560 \mathrm{~mm}^{4}$

\section{2)}

$=11.42 \mathrm{~mm}$

$=16050 \mathrm{~mm}^{3}$

(8000

$\mathrm{mm}^{3}$

$=1140 \mathrm{~mm}^{4}$

$=144000000 \mathrm{~mm}^{6}$

\section{$12337.76 \mathrm{Mpa}$ \\ 3.26E-04 Mpa}

Analisa Momen Kapasitas Penampang

Periksa terhadap tekuk lokal sayap (flange)

$\lambda=\frac{b_{f}}{2 . t_{f}}=8,33$

$\lambda_{p}=\frac{170}{\sqrt{f_{y}}}=10,70$

$\lambda r=\frac{370}{\sqrt{f y-f r}}=31,58$

Syarat : $\lambda<\lambda p<\lambda r$ (Penampang Kompak)

Gambar 7b. Diagram tegangan Model 1-1

Dari diagram regangan dan tegangan ini ini dihitung besarnya gaya $C$ (Compression), $T$ (Tension) dan jarak lengan ( $\boldsymbol{\gamma} d$ ) sehingga momen kapasitas penampang $M_{n}$ bisa dihitung. Nilai momen ini diambil sesaat sebelum leleh yaitu pada $\mathrm{P}=4.5 \mathrm{kN}$.

$$
\begin{aligned}
C & =A_{C} * \boldsymbol{\sigma} \\
& =\left(\left(\mathrm{b}_{\mathrm{f}} * \mathrm{t}_{\mathrm{f}}\right)+\left(\mathrm{h}_{\mathrm{w}} / 2 * \mathrm{t}_{\mathrm{w}}\right)\right) * \boldsymbol{\sigma} \\
& =((50 * 3)+(90 / 2 * 2)) * 252.24 \\
& =60.537,6 \mathrm{~N} \\
& =60,54 \mathrm{kN} \\
T & =A_{T} * \boldsymbol{\sigma} \\
& =\left(\left(\mathrm{b}_{\mathrm{f}} * \mathrm{t}_{\mathrm{f}}\right)+\left(\mathrm{h}_{\mathrm{w}} / 2 * \mathrm{t}_{\mathrm{w}}\right)\right) * \boldsymbol{\sigma} \\
& =((50 * 3)+(90 / 2 * 2)) * 231.17 \\
& =55480.8 \mathrm{~N} \\
& =55.48 \mathrm{kN} \\
r d & =((50 * 3) * 46.5+(45 * 2) * 22.5) /(50 * 3+45 * 2)) * 2 \\
& =75 \mathrm{~mm} \\
M_{n 1} & =C^{*}{ }_{r} d=4540320 \mathrm{Nmm}=4.54 \mathrm{kNm} \\
M_{n 2} & =T^{*}{ }_{r} d=4161060 \mathrm{Nmm}=4.16 \mathrm{kNm}(*)
\end{aligned}
$$

Periksa terhadap tekuk lokal badan (web)

$\lambda=\frac{h}{t w}=45$

$\lambda_{p}=\frac{1680}{\sqrt{f_{y}}}=109,2$

$\lambda_{r}=\frac{2550}{\sqrt{f_{y}}}=165,75$

Syarat : $\lambda<\lambda p<\lambda r$ (Penampang Kompak)

Periksa terhadap tekuk torsi lateral in elastis

$L p=790 . \frac{\text { ry }}{\sqrt{f y}}=586.24 \mathrm{~mm}$

$f_{r}=115$ Mpa (untuk las)

$f_{L}=f_{y}-f_{r}=122 \quad \mathrm{Mpa}$

$L r=r y\left(\frac{x L}{f L}\right) \sqrt{1+\sqrt{1+X 2 f L^{2}}}=2139 \mathrm{~mm}$

$\mathrm{C}_{\mathrm{b}}=1.35$

$M r=S x(f y-f r)=1952964 \mathrm{Nmm}$

$M p=Z x . f y=4260240 \mathrm{Nmm}$

Terjadi tekuk torsi lateral pada penampang kompak dgn $L p<L<L r$ maka $M n$ didekati dengan: 


$$
\begin{aligned}
M n & =C b\left(M r+(M p-M r)\left(\frac{L r-L}{L r-L p}\right)\right) \\
& =4219429 N m m \\
& =4.22 \mathrm{KNm}<M p
\end{aligned}
$$

Kuat geser nominal

$$
\begin{aligned}
\text { Syarat } \quad \frac{h}{t w} & \leq \frac{1100}{\sqrt{f y}} \\
45 & <75 \quad--->\text { OK } ! \\
V n=0.6 f y w . A w & =25561 \mathrm{~N}
\end{aligned}
$$

\section{Validasi Numerik dengan software ANSIS}

Tahapan dalam ANSYS Workbench versi 14.5 adalah:

1. Tahap Engineering Data, mendefinisikan material jenis Structural Steel Non Linier dengan sistem multilinier isotropic, dan dimasukkan nilai material.

2. TahapGeometry, model benda uji dibuat $3 D$ dengan software Autocad, kemudian diimport ke dalam software ANSYS dengan format iges. Pemodelan benda uji dalam ANSYS adalah seperti pada gambar 8 .

3. Tahap Model dan Set Up, pada tahap ini contact body antar elemen, jenis perletakan, dan load step yang akan diaplikasikan pada model benda uji sesuai dengan tahapan pemberian beban yang dilakukan pada saat pengujian eksperimen. Ukuran mesh dari model benda uji $25 \mathrm{~mm}$.

4. Tahap Solution and Result, dalam tahap ini akan diperoleh output dari ANSYS. Keruntuhan dari analisa ANSYS ini seperti digambarkan pada gambar 10.

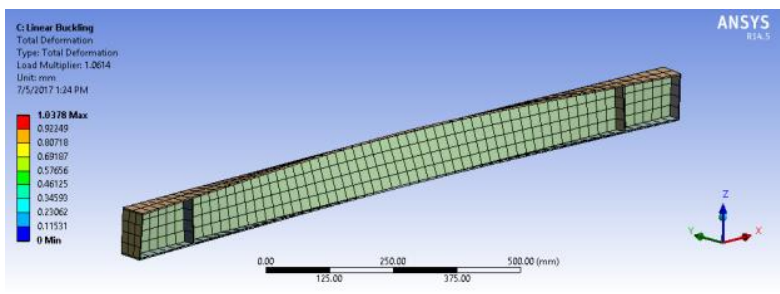

Gambar 10. Tekuk torsi lateral balok baja I built-up sesuai ANSIS

Perhitungan momen dihitung dari hubungan beban-lendutan pada saat $P$ mencapai kondisi in elastic, pada kondisi ini dilihat nilai tegangannya kemudian dihitung nilai $M_{n}$. Dalam hal ini diperoleh nilai $M_{n}=4048452 \mathrm{Nmm}=\mathbf{4 . 0 5} \mathrm{KNm}$

\section{PENUTUP \\ Simpulan}

Berdasarkan hasil penelitian dengan pengujian eksperimen, dan perhitungan analitis sesuai SNI 031729-2002, maupun validasi numerik dengan ANSYS, dapat diambil beberapa kesimpulan seperti berikut:

1. Kapasitas lentur balok baja I built-up berdasarkan eksperimen diperoleh $4.16 \mathrm{KNm}$, berdasarkan perhitungan manual sesuai SNI 03-1729-2002 diperoleh 4.22 KNm, sedangkan dari ANSYS diperoleh $4.05 \mathrm{KNm}$. Dari nilai-nilai ini menunjukkan bahwa kapasitas lentur berdasarkan eksperimen, SNI 03-1729-2002, dan ANSYS adalah tidak jauh beda.

2. Berdasarkan pengamatan jenis keruntuhan yang terjadi pada balok baja profil I built up ini adalah keruntuhan tekuk torsi lateral meskipun besarnya torsional tidak diukur. Hal ini terjadi karena stiffner hanya di pasang di tumpuan, sehingga kurang memadainya lateral support dalam menahan tekuk ke samping.

\section{Saran}

Berdasarkan kesimpulan di atas dapat di ambil beberapa saran-saran seperi berikut:

1. Untuk pengujian eksperimental di laboratorium sebaiknya untuk masing-masing model benda uji dibuat 3 buah.

2. Untuk penelitian selanjutnya dapat dilakukan pengujian balok baja I built-up dengan adanya pengaruh lateral support terhadap kapasitas lentur balok baja I built-up.

\section{DAFTAR PUSTAKA}

Sundari ,T. 2017. Perilaku Balok Baja I Non Prismastis (Tapered Beam). Thesis. Jurusan Teknik Sipil Fakultas Teknik Universitas Brawijaya Malang

Anonim. 2002. Standar Nasional Indonesia 03-17292002 Tata Cara Perencanaan Struktur Baja 
untuk Bangunan Gedung. Departemen Pekerjaan Umum

Asgarian, B., Soltani, M,. and Mohri, F. Lateral Torsional Buckling of Tapered Thin Wall Beams with Arbitary Sross-Section. Thin Wall Structures 62 (2013) 96-108.

Bhurke, K. N et al. 20013. Strength of Welded Plate Girder with Tapered Web. International Journal of Engineering Research and Applications. ISSN: 2248-9622, Vol. 3, Issue 5, pp. 19471951.

Blodgett, O.W. 1976. Design of Welded Structures. Cleveland Ohio: The James F. Lincoln Arc Welding Foundation.

Chen, W.F. and Lui, E. M. 1987. Structural Stability Theory and Implementation. New York: Elsevier Science Publishing Co., Inc.

Dewobroto, W. 2011. Struktur Baja Perilaku, Analisis, dan Desain-AISC 2010. Jakarta: Grand Melia.

Gere, J. M. 2004. Mechanics of Materials. Belmont, USA. Thomson Learning.

Pandiangan R. 2013. Analisa Non Linier Tekuk Lateral pada Balok Baja Profil I Non Prismatis dengan Program Abaqus. Tugas Akhir. Departemen Teknik Sipil Fakultas Teknik Universitas Sumatera.

Salmon, C. G, dkk. 1996. Struktur Baja Desain dan Perilaku, Jakarta: P.T. Gramedia Pustaka Utama.

Segui, William T. 2007. Steel Design. Stamford, USA : Cengage Learning.

Setiawan, A. 2008. Perencanaan Struktur Baja dengan Metode LRFD (Berdasarkan SNI 03-17292002). Jakarta: Erlangga.

Suhendro, B. 2000. Teori Model Struktur dan Teknik Eksprimen. Yogyakarta: Beta Offset

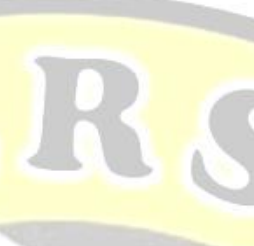

n

